\title{
Non-random Cell Distributions in Continuous-flow Cultures of Tetrahymena
}

\author{
By P. B. SUHR-JESSEN, K.-H. COHR, H. E. BUHSE, JR*AND \\ L. RASMUSSEN \\ The Biological Institute of the Carlsberg Foundation, \\ I6 Tagensvej, DK-2200 Copenhagen N, Denmark
}

(Received 3 May 1977)

\begin{abstract}
Mixing techniques, which kept killed or non-multiplying Tetrahymena pyriformis in fully randomized suspensions for short test periods (hours), were inadequate for ideal mixing of normal, untreated cells during long periods of growth (weeks). This poor mixing resulted in inhomogeneity in the cell suspension and invalidated calculation of cell multiplication rates in continuous-flow cultures. The development of such inhomogeneities was prevented by the combined use of large propeller blades for mixing and a growth-limiting substrate.
\end{abstract}

\section{INTRODUCTION}

A central assumption of many experiments involving continuous-flow culture is the random distribution of the cells in the culture volume. In this report we demonstrate nonrandom cell distributions during long-term cultivation of the free-swimming ciliate Tetrahymena pyriformis under culture conditions, where short-term model tests (Rasmussen et al., 1974) had indicated ideal mixing.

\section{METHODS}

Axenic populations of Tetrahymena pyriformis, strain GL-8, phenoset A (Borden, Whitt \& Nanney, 1973) were grown in $2 \%(\mathrm{w} / \mathrm{v})$ proteose peptone broth (Difco) supplemented with $0 . \mathrm{I} \%(\mathrm{w} / \mathrm{v})$ liver fraction and salts (Plesner, Rasmussen \& Zeuthen, 1964). The culture chamber was coated with Teflon and contained about $45 \mathrm{ml}$ of medium stirred at 300 rev. $\mathrm{min}^{-1}$ with a magnet $(22 \times 4 \mathrm{~mm})$ on the bottom of the culture chamber (Rasmussen et al., 1974). The chamber contained several ports through which sterile nutrients and air were added or cell suspension and excess air removed (see Cohr \& Suhr-Jessen, 1975). Samples of a known volume of cell suspension were automatically removed from the culture at preset time intervals and fixed with formaldehyde. The cells were later counted either electronically or, if the cell density was very low, by visual counting of cells in a small volume. The culture chamber differed from one previously described (Cohr \& Suhr-Jessen, 1975) in that the magnet used for mixing was smaller and lacked propellers (Curds \& Cockburn, 1971; Rasmussen et al., 1974). The culture chamber was placed in a water thermostat regulated at $28^{\circ} \mathrm{C}$.

The population density in a continuous culture can be described by the following equation (Monod, 1950) provided that the cells in the culture are distributed in a random fashion and assuming that mean cell mass remains constant (see Discussion):

$$
\ln \frac{N_{t}}{N_{0}}=(\mu-D) t
$$

where $N_{0}$ and $N_{t}$ denote cell concentrations at times o and $t$ respectively; $\mu$, the specific growth rate, is equal to the natural logarithm of 2 divided by the doubling time; and $D$, the dilution rate, equals the flow rate, $F\left(\mathrm{ml} \mathrm{h}^{-1}\right)$, divided by the culture volume, $V(\mathrm{ml})$.

* Present address: Department of Biological Sciences, University of Illinois, Chicago, Illinois 60680, U.S.A. 
The efficiency with which the magnet stirred the nutrient medium in the culture chamber was tested as follows: (i) a drop of a crystal violet solution required only a few seconds for full dispersion (Monod, I950); (ii) radioactive phosphate in solution was diluted at the same rate as formaldehyde-fixed cells (Rasmussen et al., 1974); (iii) cells in which division was blocked by cycloheximide (10 $\mu \mathrm{g} \mathrm{ml}^{-1}$ ) were diluted at rates predicted on the assumption that the cells were randomly distributed in the culture volume. Since these results seemed to indicate ideal mixing of non-dividing cells, we assumed - wrongly - that the mixing would also be adequate for multiplying cells.

\section{RESULTS}

The cells multiplied during the first $28 \mathrm{~h}$ (Fig. I) with a calculated doubling time of $2 \cdot 69 \mathrm{~h}$ (growth rate, $0.258 \mathrm{~h}^{-1}$ ) in agreement with results from batch cultures under similar conditions (Zeuthen, I974). Since the growth rate exceeded the dilution rate, the population density increased. From $4 \mathrm{I}$ to $59 \mathrm{~h}$ growth rate equalled dilution rate and the population doubling time was $\mathrm{II} \cdot 59 \mathrm{~h}$. From 59 to $\mathrm{I} 3 \mathrm{I} \mathrm{h}$ the dilution rate was increased to $0 \cdot 3 \mathrm{I} \mathrm{h} \mathbf{h}^{-1}$. Initially, the population density decreased, but eventually a steady state was established at 17000 cells $\mathrm{ml}^{-1}$. At this time the growth rate again equalled the dilution rate and the population doubling time was calculated to be $2 \cdot 24 \mathrm{~h}$. At I3I h the dilution rate was returned to $0.059 \mathrm{~h}^{-1}$ and the population density increased at a rate corresponding to that observed during the first $28 \mathrm{~h}$ of the experiment. Thus the experimental system produced data which were reproducible and in agreement with previously reported results (Zeuthen, 1974).

The experiment depicted in Fig. 2 involved dilution rates which were very high compared to the maximum cell multiplication rate, and the population densities decreased to low values before termination. For the final $20 \mathrm{~h}$ (Fig. $2 a$ ) the doubling time was calculated to be $0.5 \mathrm{~h}$ under the assumption that the cell suspension was homogeneous. This value seemed unlikely and prompted the experiment shown in Fig. $2(b)$. Here the flow pump was stopped

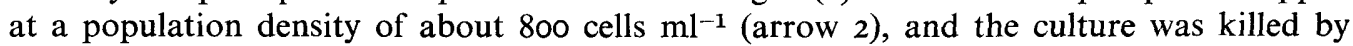
addition of $0.5 \mathrm{ml}$ of $40 \%(\mathrm{w} / \mathrm{v})$ formaldehyde and samples were removed at 4 min intervals (open circle with bars). Addition of formaldehyde caused the population density of the culture vessel to increase fivefold, i.e. to about 4000 cells $\mathrm{ml}^{-1}$. This indicated that there were inhomogeneities in the cell suspension; one or more 'sub-compartments' contained, before fixation, at least fourfold more cells than the free cell suspension.

Macroscopic observations of the culture vessel revealed a light brown to black ring at the upper margin of the air-medium interface. This ring was first visible within a few days after the inoculation. Microscopic examination of the ring showed that it contained many cells, some of which were deformed.

\section{DISCUSSION}

We report the population data here as number of cells $\mathrm{ml}^{-1}$ and not as is usual in chemostat equations as mass volume ${ }^{-1}$. Mass cell ${ }^{-1}$ in Tetrahymena may indeed vary greatly (Hamburger \& Zeuthen, 1957; Curds \& Cockburn, 197I), but in our hands the cells did not change their mean size to any appreciable extent over several days at high dilution rates $\left(\mathrm{I} \cdot 48 \mathrm{~h}^{-1}\right)$. Thus the results presented in the last part of Fig. 2(a) cannot be fully explained by a reduction in mean cell mass.

The cells apparently formed several sub-populations as a result of inadequate mixing. They were highly mobile and congregated in response to environmental factors such as increased nutrient and oxygen supplies wherever the velocity of the cells exceeded the velocity of the extracellular fluid, for instance along the chamber wall and the air-medium interface. These cells formed one sub-population. The fixative prevented maintenance of this population by immobilizing the cells. Another sub-population was found on the chamber wall in a ring at the interface between the medium and the air phase. Microscopic examination of this ring showed cells embedded in a brownish material. These cells appeared nonmotile, and morphologically deformed, and remained attached to the wall even after the addition of formaldehyde (wall growth). Most of these cells were viable as demonstrated by 


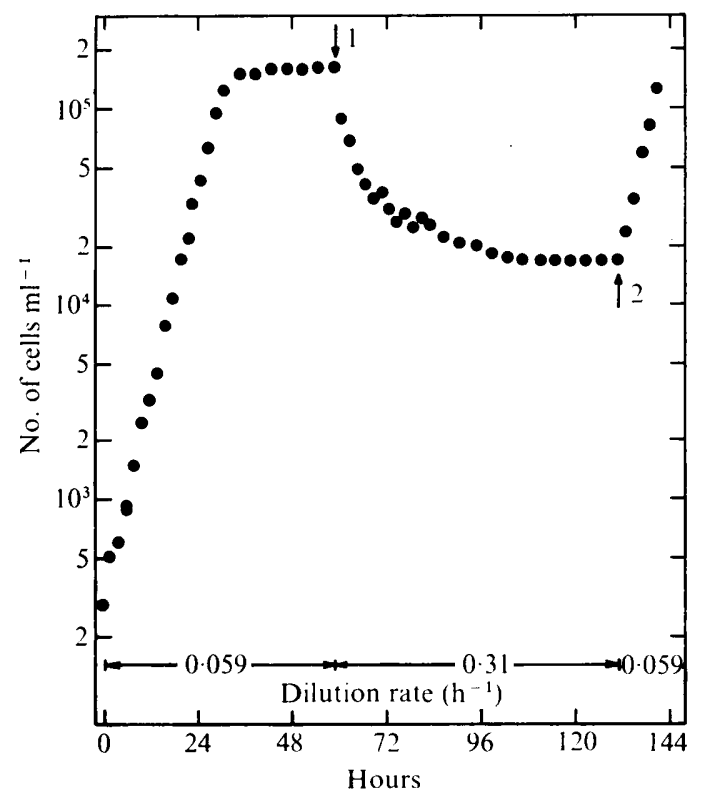

Fig. I. Concentration of Tetrahymena pyriformis in a continuous-flow culture as described in Methods.

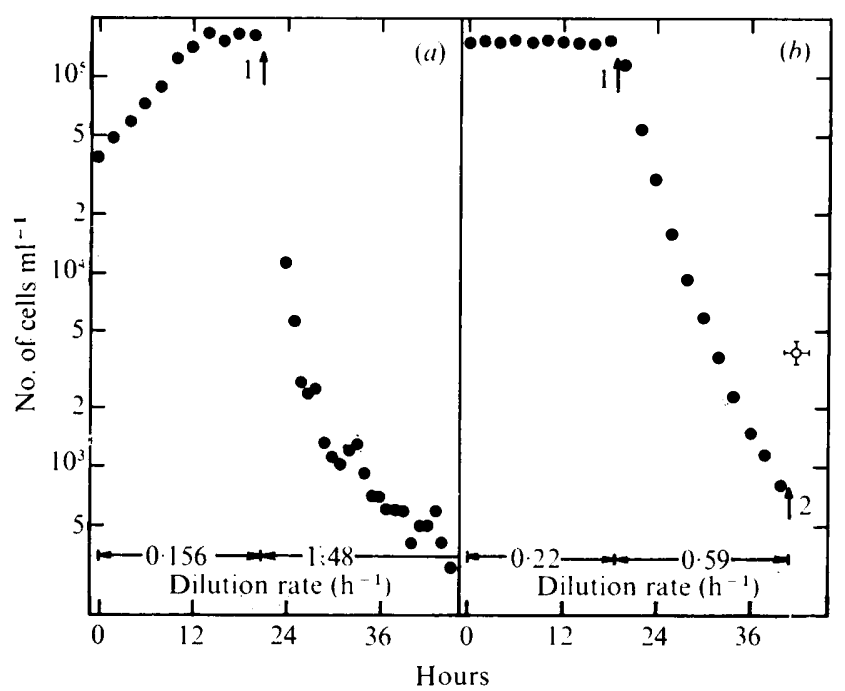

Fig. 2. Concentration of Tetrahymena pyriformis in two continuous-flow cultures. (a) At arrow I, the dilution rate $(D)$ was changed from $0.156 \mathrm{~h}^{-1}$ to $\mathrm{I} \cdot 48 \mathrm{~h}^{-1}$. (b) At arrow I, $D$ was changed from $0.22 \mathrm{~h}^{-1}$ to $0.59 \mathrm{~h}^{-1}$; at arrow $2, D$ was changed from $0.59 \mathrm{~h}^{-1}$ to zero and $2 \mathrm{ml} 0.5 \%$ (w/v) trypan blue was added to the cultures. Five minutes later $0.5 \mathrm{ml} 40 \%$ formaldehyde was added. The open circle with bars represents the range of cell numbers after this treatment.

their exclusion of trypan blue (Phillips, I973; P. B. Suhr-Jessen and L. Rasmussen, unpublished observations). Offspring of cells from this sub-population may be steadily released into the suspension fluid and obscure the rate with which the cells in the suspension multiplied.

In further experiments we have used a magnet with large propeller blades passing close to the wall from the top to the bottom of the culture volume and a growth-limiting nutrient 
medium containing $0.5 \%$ proteose peptone (Cohr \& Suhr-Jessen, I975; Suhr-Jessen, Stewart \& Rasmussen, 1977). These cultures had steady-state population densities of about I 50000 cells $\mathrm{ml}^{-1}$ for more than a month without any visible ring on the culture chamber at the interface between the medium and the air phase. Furthermore, we observed no sign of insufficient mixing upon fast dilution to very low cell densities like those presented in Fig. $2(b)$.

This study showed that the combination of a rich nutrient medium and small propeller blades failed to keep swimming, multiplying Tetrahymena randomly distributed in suspensions for long periods. As a consequence of our observations we suggest that results obtained by several workers (Contois, I959; Curds \& Cockburn, I97I ; Herbert, Phipps \& Tempest, I965; Righelato \& Pirt, 1967; Steensland, I973) in part could be due to technical errors and should be re-examined. We suggest that mixing efficiency be tested after completion of the experiments with continuous-flow cultures as we have previously done (Cohr \& SuhrJessen, 1975) and not, as is usual, in separate tests (Monod, 1950; Rasmussen et al., I974).

We are pleased to thank Professor Erik Zeuthen and Dr Helge A. Andersen of this Institute for their helpful criticism at all stages of this work. We also thank Drs Eduardo Orias and Charles T. Roberts, Jr, Santa Barbara, California, and Hiroshi Miyamoto, Kinki University School of Medicine, Osaka, Japan, for their comments, and Mrs Birthe Dohn for excellent technical assistance.

This work was supported by a grant from the Edna McConnel Clark Foundation to H.E. Buhse and grants from the Carlsberg Foundation to Peter B. Suhr-Jessen and KarlHeinz Cohr.

\section{REFERENCES}

Borden, D., Whitt, G. S. \& Nanney, D. L. (1973). Electrophoretic characterization of classical Tetrahymena pyriformis strains. Journal of Protozoology 20, 693-700.

Cohr, K.-H. \& Suhr-Jessen, P. B. (1975). An apparatus for cultivation of cell suspensions in continuous flow cultures. Comptes rendus des travaux du Laboratoire Carlsberg 40, 205-2 I3.

ConToIs, D. E. (1959). Kinetics of bacterial growth: relationship between population density and specific growth rate of continuous cultures. Journal of General Microbiology 2x, 40-50.

Curds, C. R. \& Cockburn, A. (I97I). Continuous monoxenic culture of Tetrahymena pyriformis. Journal of General Microbiology 66, 95-108.

Hamburger, K. \& Zeuthen, E. (1957). Synchronous divisions in Tetrahymena pyriformis as studied in an inorganic medium. Experimental Cell Research $\mathbf{3}$, 443-453.

Herbert, D., Phipps, P. J. \& Tempest, D. W. (I965). The chemostat: design and instrumentation. Laboratory Practice I4, I I50-I I6I.

Monod, J. (I950). La technique de culture continué. Théorie et applications. Annales de l'Institut Pasteur 79, 390-4IO.

Phillips, H. J. (I973). Dye exclusion tests for cell viability. In Tissue Culture Methods and Applica- tions, pp. 406-408. Edited by P. K. Krause and M. K. Patterson, Jr. New York: Academic Press. Plesner, P., Rasmussen, L. \& Zeuthen, E. (I964). Techniques used in the study of synchronous Tetrahymena. In Synchrony in Cell Division and Growth, pp. 543-563. Edited by E. Zeuthen. New York: Interscience Publishers.

Rasmussen, L., Cohr, K.-H., Buhse, H. E. Jr. \& Zeuthen, E. (I974). Automatic cell counting in continuous flow cultures of Tetrahymena pyriformis. Journal of Protozoology 21, 552-555.

Righelato, R. C. \& PiRT, S. J. (I967). Improved control of organism concentration in continuous cultures of filamentous microorganisms. Journal of Applied Bacteriology 30, 246-250.

Suhr-Jessen, P. B., Stewart, J. M. \& Rasmussen, L. (1977). Timing and regulation of nuclear and cortical events in the cell cycle of Tetrahymena pyriformis. Journal of Protozoology (in the Press). STEensland, H. (I973). Continuous culture of a sewage fungus Fusarium aquaeductuum. Archiv für Mikrobiologie 93, 287-294.

ZEUTHEN, E. (1974). A cellular model for repetitive and free-running synchrony in Tetrahymena and Schizosaccharomyces. In Cell Cycle Controls, pp. I-30. Edited by I. Cameron, G. Padilla and A. Zimmerman. New York: Academic Press. 